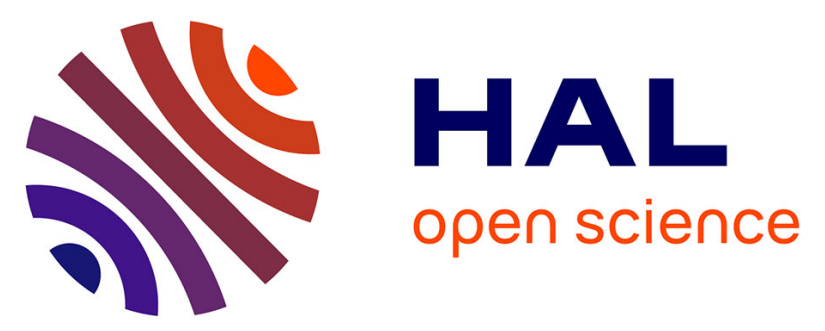

\title{
New climatic approaches to the analysis of the middle Paleolithic sequences: Combined taxonomic and isotopic charcoal analyses on a Neanderthal settlement, Les Canalettes (Aveyron, France)
}

Benjamin Audiard, Liliane Meignen, Thierry Blasco, Giovanna Battipaglia, Isabelle Théry-Parisot

\section{To cite this version:}

Benjamin Audiard, Liliane Meignen, Thierry Blasco, Giovanna Battipaglia, Isabelle Théry-Parisot. New climatic approaches to the analysis of the middle Paleolithic sequences: Combined taxonomic and isotopic charcoal analyses on a Neanderthal settlement, Les Canalettes (Aveyron, France). Quaternary International, 2020, 10.1016/j.quaint.2020.11.042 . hal-03034543

\author{
HAL Id: hal-03034543 \\ https://hal.science/hal-03034543
}

Submitted on 30 Dec 2020

HAL is a multi-disciplinary open access archive for the deposit and dissemination of scientific research documents, whether they are published or not. The documents may come from teaching and research institutions in France or abroad, or from public or private research centers.
L'archive ouverte pluridisciplinaire $\mathbf{H A L}$, est destinée au dépôt et à la diffusion de documents scientifiques de niveau recherche, publiés ou non, émanant des établissements d'enseignement et de recherche français ou étrangers, des laboratoires publics ou privés. 


\section{Introduction}

The Upper Pleistocene is a long period marked by climate and environmental changes in Europe, and it is heavily influenced by the last phase of glaciation. Understanding the way in which ancient societies faced environmental conditions is critical issues for prehistorians. Charcoal analysis is a reliable method to reconstruct the regional changes in forests (see previous proceedings from the 4th, 5th, and 6th International Anthracology Meetings) (Badal et al., 2011; Damblon, 2008; Ludemann and Nelle, 2015). The frequency of taxa and their changes over time are interpreted by analogy with current floristic compositions, as a diachronic history of the structure and ecology of forest stands. Furthermore, anthracology provides complementary information on the wood supply and its management by ancient societies (Olive and Taborin, 1987; Théry-Parisot, 1998, 2001).

However, different limits in anthracology can be identified for Upper Pleistocene sequences. Indeed, these sequences sometime exhibit anthracologic assemblages with low taxonomic diversity, mainly represented by Pinus species as woody refuges in a steppe landscape or as broad forest cover. Moreover, anthracology does not provide information on forest density. Most of the time, the lack of taxonomic diversity does not allow us to specify whether it comes from a monospecific environment or is attributable to human practices (i.e., wood selection). In addition, Pleistocene anthracological assemblages are exposed to significant post-depositional processes, which reduce the number, size, and quality of the charcoal (Chrzazvez et al., 2014; Théry-Parisot et al., 2010). Methodological studies from anthracology suggest a relatively significant number of charcoal remains from relatively long human occupations are required to provide a reliable quantitative signal of past environments (Chabal, 1992, 1997). Thus, low numbers of charcoal fragments in Pleistocene sequences are sometime limited to a qualitative interpretation with a low stratigraphic resolution. To overcome this limitation, complementary approaches have recently been developed.

In recent decades, studies focusing on the $\delta^{13} \mathrm{C}$ isotopic signals of plants have provided a reliable method to reconstruct past climatic and environmental conditions. During plant absorption of atmospheric $\mathrm{CO}_{2}$, a discrimination $(\Delta)$ of carbon isotopes occurs. It is defined, in $\mathrm{C} 3$ metabolism, as the result of discrimination against ${ }^{13} \mathrm{C}$ induced by stomatal conductance $(\mathrm{a}=4.4 \%$ ) and the RuBisCO enzyme during carboxylation $(b \simeq 30 \%$ ), with an intensity that depends on the ratio of intracellular $\mathrm{CO}_{2}$ to atmospheric $\mathrm{CO}_{2}$ content (ci/ca) : $\Delta \simeq \mathrm{a}+(\mathrm{b}-\mathrm{a}) \mathrm{ci} / \mathrm{ca}$ (1) (Farquhar and Lloyd, 1993; Farquhar et al., 1982). Thus, changes in stomatal opening, controlled by environmental and climatic parameters (including atmospheric parameters), constrain the $\delta^{13} \mathrm{C}$ record in the plant (Farquhar et al., 1989). Correlation between the $\delta^{13} \mathrm{C}$ wood signal and different stress factors (drought, high temperatures, etc.) can be observed over scales at various resolutions (seasonal wood, tree-rings, tree-ring clusters) (Cernusak and English, 2015; McCarroll and Loader, 2004). In particular, correlations between the wood $\delta^{13} \mathrm{C}$ signal and water availability parameters were observed in a major study, which corresponds to the first recurrent limiting factor (Battipaglia et al., 2014; Dawson et al., 2002; Farquhar and Richards, 1984; Gessler et al., 2014; Panek and Goldstein, 2001; Warren et al., 2001). In the presence of optimal levels of atmospheric moisture or in the global warming, temperature or Irradiation also dominate the relationship between isotopic and climatic signals (Gagen et al., 2007; McCarroll and Pawellek, 2001; Seftigen et al., 2011).

The analysis of the isotopic signal $\left(\delta^{13} \mathrm{C}\right)$ in charcoal remains from archaeological contexts is an additional climatic proxy, which raises new perspectives. Pioneering research have attested to its potential to reconstruct long-term climatic trends, in both the Holocene (Aguilera et al., 2012; Baton 
et al., 2017; Ferrio et al., 2006; Fiorentino et al., 2012a; Masi et al., 2013; Voltas et al., 2008) and the Pleistocene archeological context (Audiard et al., 2019; Hall et al., 2008; Vernet et al., 1996). However, the resolution and application of isotope analyses in Pleistocene sequences is an important issue. Indeed, certain issues are common for all isotopic studies on charcoal. For example, the effect of charring on isotopic signal evolution is now well documented. The measurement of the carbon content $(\% C)$ as an indicator of the carbonization state allow for isotopic signal corrections (Audiard et al., 2018; Ferrio et al., 2006; Resco et al., 2011; Steinbeiss et al., 2006; Voltas et al., 2008).

In contrast, major interpretative and methodological challenges must be investigated, according to specificity of the context and chronology or different anthracological assemblage features. Thus, the method needs to be adapted for each archeological site. In particular, the type of charcoal deposit (spread, hearth), the sampling method (manual, or sifting), the intensity of the taphonomic processes and fragmentation (size, mass and number of charcoal samples; reliability of taxonomic identification) can restrict the potential of the isotopic study (Audiard et al., 2019). In addition, the taphonomic processes and the nature of the sediment can lead to exogenous carbon contamination and necessitate pretreatment, which can decrease the mass of charcoal (Vaiglova et al., 2014). Moreover, interpretation of the $\delta^{13} \mathrm{C}$ signal presents several challenges, particularly for the Pleistocene period, for which we lack understanding of the signal response over longer periods and under different environmental conditions from those of the present day. Indeed, we are only able to analyze a mean signal from isolated charcoals. Thus, the resulting values have automatically integrated the intra-individual variability, the intra-species variability (inter-individual variability) and the interspecies variability (Francey, 1981; Leavitt, 2002, 2007, 2010; Leavitt and Lara, 1994; Leavitt and Long, 1986; Ramesh et al., 1985; Robertson et al., 1997; Tans and Mook, 1980). Consequently, the use of $\delta^{13} \mathrm{C}$ from charcoal of Pleistocene sequences raises questions about (i) the nature of the isotopic signal obtained and (ii) the possibility to use it as a climatic and environmental proxy of low frequency changes, despite significant natural variability and a limited amount of charcoal for analyses. Lastly, since the variability of $\delta^{13} \mathrm{C}$ is taxon-dependent, it is crucial to analyse the same taxon for the entire sequence and to base the interpretations on current studies on the same taxon.

In addition to environmental and methodological issues, the relationship between the isotopic signal of charcoal and the wood collected environment raises questions about the impact of the diversification of collection areas on the isotopic signal. The integration of the anthracological data and the isotopic signal could then allow to discuss the Neanderthal behaviours in relation to the wood harvesting and environmental evolutions.

The methodological bases of the application of $\delta^{13} \mathrm{C}$ to Pleistocene can be found in (Audiard et al., 2018) and a first application to the study of the Middle Paleolithic sequence of La Combette (Vaucluse, France) has shown the potential of $\delta^{13} \mathrm{C}$ as a paleoclimatic proxy (Audiard et al., 2019). In the continuation of this work, we present here, the first application of the method to charcoal, with individual analyses from a major Middle Paleolithic settlement: Les Canalettes rock shelter (Aveyron, France). The results of previous paleoenvironmental studies from les Canalettes (fauna, microfauna, geoarcheology and anthracology) lead to divergent interpretations of the evolution of climatic conditions over the sequence (Brugal, 1993; Kervazo et al., 1995; Marquet, 1993, 1995; Théry-Parisot, 1998; Vernet, 1993). Our aim was to enrich the sequence of new data increasing the resolution in order to document the paleoenvironmental context and to discuss human/environment interactions at the local scale. The variability and the climatic resolution of the isotopic signal will be discussed with respect to previous, complementary paleoenvironmental results. In addition, methodologic issues will be addressed regarding previous isotopic works in paleolithic sequences with charcoal grouping analyses (Audiard et al., 2019). 


\section{Archaeological context and previous data}

\section{General context}

Les Canalettes site is a rock shelter (680 $\mathrm{m}$ in altitude) located in a wide alveolus (extended Polje) of the Larzac Causse Plateau (700 to $900 \mathrm{~m}$ ) in the Aveyron region (Figure 1). Oriented southeastward in a wider karstic depression (Canaule) the shelter is separated by a tectonic escarpment of the Vallée du Durzon (550 m in altitude, tributaries of the Dourbie) (Ambert, 1993).The Les Canalettes rock shelter holds a strategic position in a natural passage between the Causse plateau and the valley, which is particularly favorable for raw material and environmental resources (Lebegue, 2012; Meignen, 1993b).

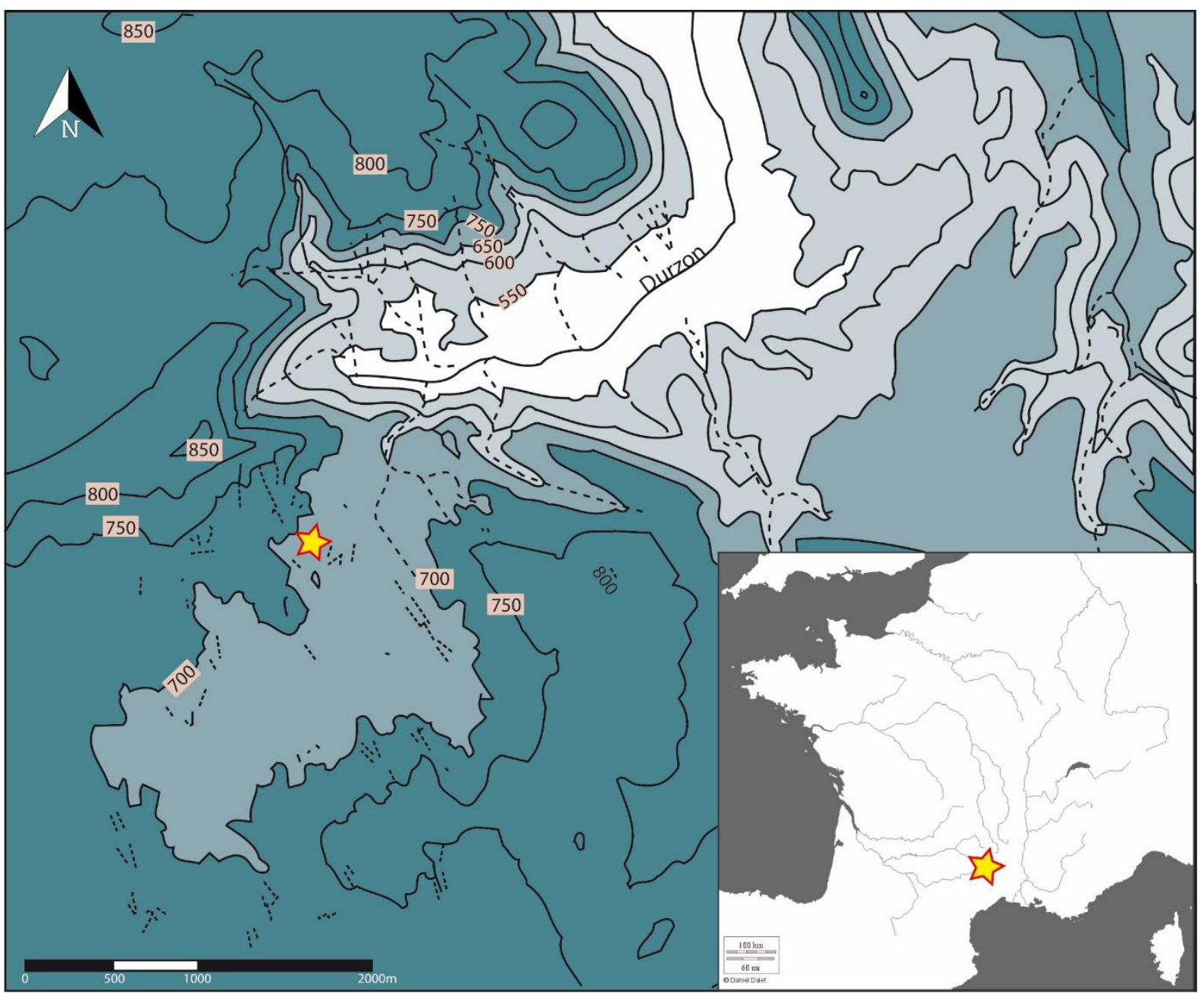

Figure 1: Location of the Middle Paleolithic site of Les Canalettes rock shelter (yellow star), on the south-east of the Larzac Causse Plateau (South-East France). Modified after Meignen, 1993.

The site presents a two-meter-thick stratigraphic sequence where numerous lithic remains assigned to the Mousterian have been found along the deposit (Figure 2). The sedimentary dynamics of the shelter are fairly homogeneous over the entire thickness of the stratigraphy, with a sedimentological composition of loose dolomitic sands more or less rich in heterometric gravel. The sequence has been divided into 4 stratigraphic units, mainly on changes in color of the sandy matrix and a decrease of coarser fraction in the middle of the stratigraphy. However, US 1 (black silty-sandy sediment, with coarser fraction mainly composed of $15-25 \mathrm{~cm}$ blocks) corresponds to a humic level of 
variable depth. The humic development is responsible of the uneven limit with US 2 (25-60 cm thick, sandy, yellow sediment with coarser fraction from small gravel to $25-30 \mathrm{~cm}$ blocks). The US 1 and 2 are impacted by runoff and percolation, principally close the wall and at the shelter limit. US 1 is represented by heterogeneous archeological material (Mousterian, Neolithic, Middle Age, Historic Period), and US 2 is mostly represented by Mousterian material with a few exceptions against the wall. In contrast, US 3 (30-60 cm thick, sandy, yellow-orange sediment with coarser fraction from gravel to block) and US 4 (25-60 cm thick, sandy, brown sediment with coarser fraction from little gravel to block) are well preserved with horizontal limits observed during excavation (US 2/3 and US 3/4) and rich Mousterian material (Ambert, 1993; Kervazo et al., 1995; Meignen, 1993a).

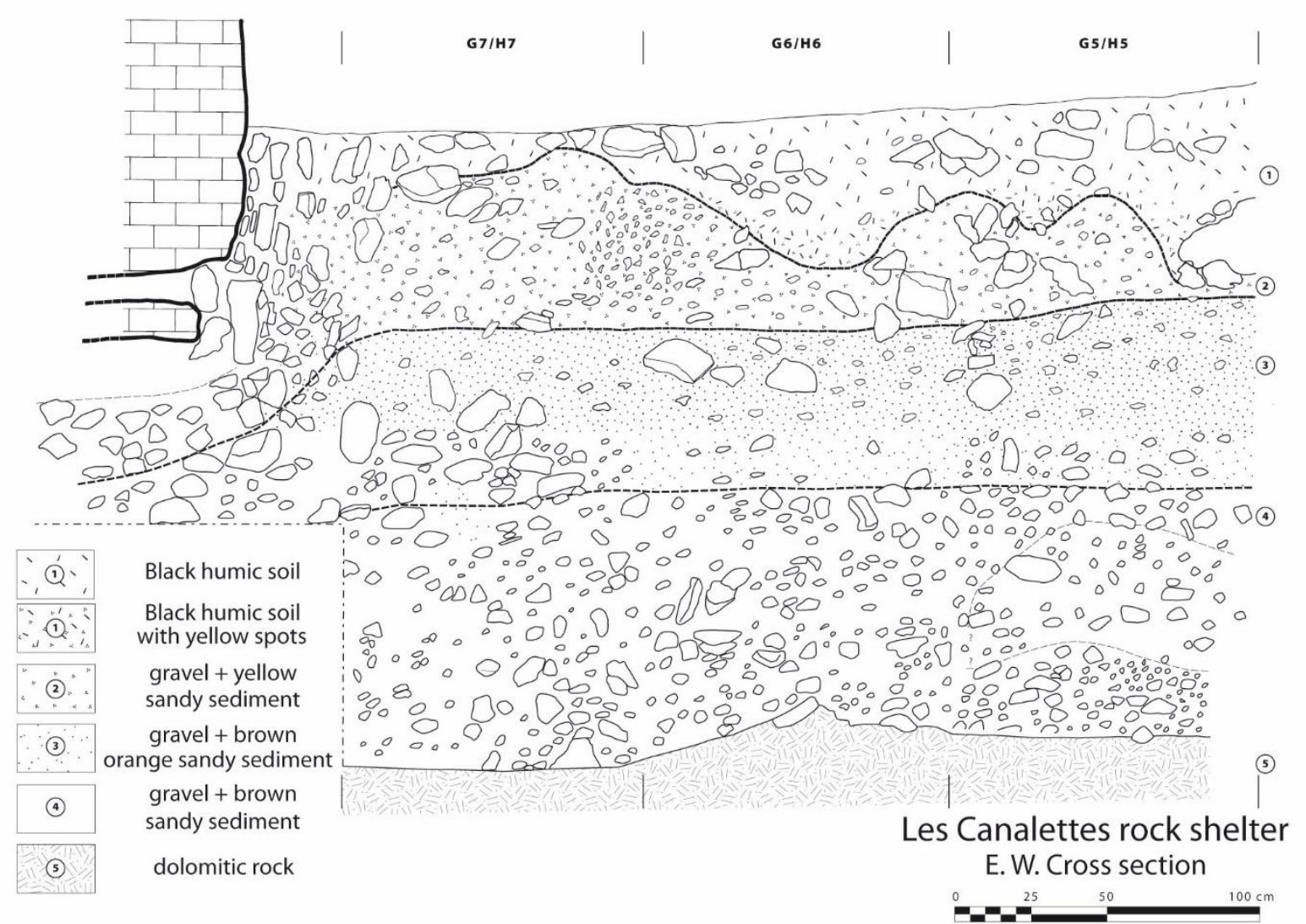

Figure 2: East-West stratigraphic cross section of Les Canalettes rock shelter. Modified after Meignen, 1993.

The geomorphologic dynamic and the lithic material indicate a relatively short and continuous deposit phase (Ambert, 1993; Meignen, 1993a). The single dating study was realized by thermoluminescence on the upper part of US 2 and indicates occupation during the MIS5a and MIS4 transition at $73500 \pm 6000$ years BP (Valladas et al., 1987).

The well-preserved archeological material and the multidisciplinary approaches enabled reconstruction of the behavior of the Neanderthals present in Les Canalettes, in a landscape long considered austere. It seems to be a long-term and recurrent occupation camp, undoubtedly seasonal (during the good season, late spring to early fall), and partly linked with easy access to abundant herbivore fauna from the plateau and forest of the alveolus (extended polje) as well as its proximity to the raw material (Brugal, 1993; Lebegue, 2012; Meignen, 1993b; Meignen et al., 2001). Moreover, Les Canalettes is also known as the site with the oldest use of the lignite as fuel (Thery-Parisot and Meignen, 2000; Théry et al., 1995, 1996), found in the same relative proportions in US 4 to 2 . This material, accessible in the valley, was used by Neanderthal either for a specific use (long fire without 
flames), (ii) or for its ease of use (harvesting, storage and transport easier than healthy wood) (ThéryParisot and Meignen, 2000).

\section{Previous results of Paleoenvironmental studies}

The multidisciplinary program at Les Canalettes has provided numerous and complementary paleoenvironmental results. But, the palynologic tests were negative and the homogeneity of the deposit only allows to define deposit conditions in temperate to cold conditions (Ambert, 1993). Similarly, the low number of identified faunal remains prevented the authors from obtaining reliable information on environmental evolution (Brugal, 1993). However, the recurrence of horse and deer throughout the sequence indicates a relatively open and temperate to cold environment. Moreover, a slight increase in hare, mammoth and marmot (one to a few remains), between US 3 and 2, allowed the author to propose a climatic degradation.

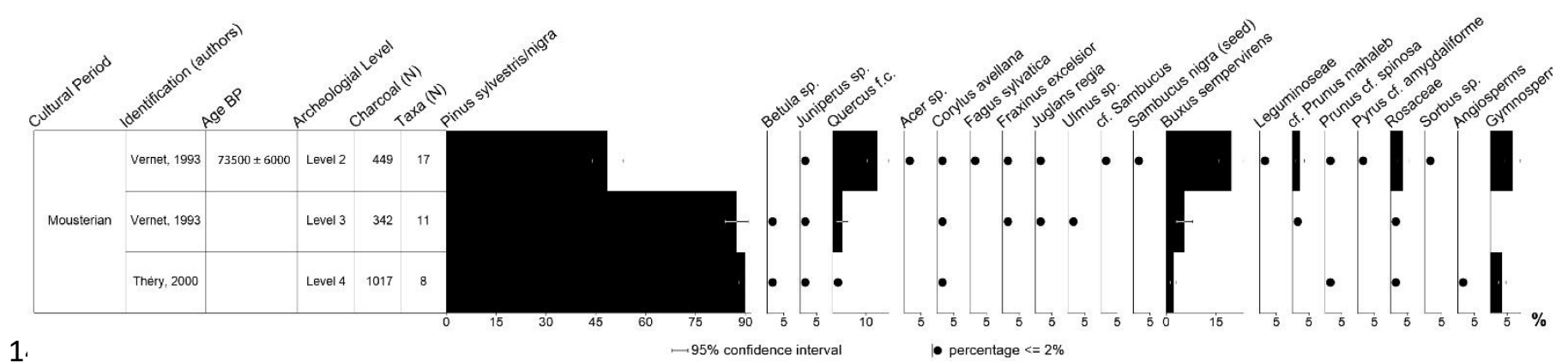

Figure 3: Anthracological diagram of the mousterian site Les Canalettes (modified according to Théry-Parisot, 1998)

The high number of charcoal remains identified (1811) provided reliable information on the paleoenvironment (Théry-Parisot, 1998; Théry-Parisot and Meignen, 2000; Théry et al., 1996; Vernet, 1993). The anthracological diagram (Figure 3) presents a consistent trend supporting progressive transformation of the environment under the effect of climate change (Théry-Parisot, 1998; Vernet, 1993) with a diversification of taxa, from 8 taxa in US 4 to 17 taxa in US 2 . US 4 is characterized by the presence of mountain taxa (Pinus, Betula and Juniperus), which largely dominate the assemblage, with a few occurrences of mesophilic (Quercus f.c., Corylus) together with xeric heliophilic taxa (Buxus, Rosaceae). US 3 is still largely dominated by pine, but mesohygrophilic taxa are diversified (UImus, Fraxinus). US 2 shows a significant increase in mesophilic elements (notably Quercus), and is enriched by new taxa (Fagus, Acer) and a marked decrease in mountain taxa.

Thus, the charcoal assemblages of US 4 and 3 are quite similar, whereas US 2 shows a marked change in the composition of the anthracological spectrum. This could suggest a change in wood harvesting behavior at US 2, but this assumption seems weak as the ecological dynamics are very consistent with changing climatic conditions. At the base of the sequence (US 4), charcoal remains suggest the existence of an open environment of pine groves that had developed under rather cold and dry conditions. Gradually, a very slight improvement in the climate is reflected in the localized development of mesophilic elements, while the frequency of mountain taxa begins to decrease. US 3 then appears to be a transition level. US 2 shows a marked change in climatic conditions and a more forest-like environment with a mixed series of pine and oak in which pine dominates but the mesophilic elements remain well represented, suggesting humid temperate conditions that were slightly cooler than current conditions. 
The anthracological assemblage thus reflects a consistent dynamic in the evolution of taxa frequencies, arguing for environmental closure related to less severe conditions and higher humidity at the top of the sequence.

Microfaunal studies have also yielded a sufficient number of identifications in each of the lower

\section{Materials and Methods}

\section{$\underline{\text { Materials }}$}

The isotopic study focused on charcoal identified as Pinus type sy/vetsris/nigra (including mugo/cembra). Indeed, pines not only composed the majority of the charcoal remains of Paleolithic sites but are also one of the most represented species in the isotopic studies of wood. Nevertheless, Pinus species cannot be anatomically discriminated. However, several studies on isotopic variability between species of the same genus reveal that it is possible to combine their signals (same response) (Gagen et al., 2006; Marshall and Monserud, 1996). Moreover, in a previous study we demonstrated that the interspecific variability tested on 3 species of pine ( $P$. nigra, $P$. sylvestris and $P$. halepensis) is lower than the intra- and inter-individual variability before and after carbonization (same effects) (Audiard et al., 2018). These analyses suggested a limited and not significant supplementary intragenus variability in a $\delta^{13} \mathrm{C}$ Pinus signal.

In order to obtain an isotopic signal at high stratigraphic resolution, the study focused on charcoal from sediment sifting of the center square G5 (low post-depositional impact). Pine charcoal from both new identifications and previous studies (I. Thery-Parisot) were isolated under a stereomicroscope. We collected 98 charcoals spread across 13 artificial sub-stratigraphic levels (décapages), with 2 to 18 charcoal samples for each one, the majority of which contained more than 10. The dominant charcoal size comprised 1 to $5 \mathrm{~mm}$, followed by less than $1 / 4$ of charcoal total between $5 \mathrm{~mm}$ and $1 \mathrm{~cm}$ and only few charcoals bigger. Considering, this size heterogeneity, the difficulty to have enough material to analyze with smaller ones and the difficulty to distinguish tree-ring due to numerous surface charcoal alteration, we used each entire charcoal as a sample without subsampling. This protocol should avoid the loss of material, with a lower number of analyses. In addition, the analysis of charcoal large enough to contain several tree-rings should lead to mean isotopic values closer to a low frequency averaged isotopic signal (long time). 
In order to study the stable carbon isotope ratios of charcoal, possible contamination of other carbon sources (e.g., carbonates, humic acid and fine rootlets) must be removed. However, the usual decontamination procedure, consisting of an acid-base-acid treatment, decreases the charcoal mass that is essential for individual analysis. Thus, we applied the method proposed by Vaiglova et al. (2014). It consists in an evaluation of the level of humic acid contamination by analyzing charcoal remains with a FTIR spectrometer. Then, if the contamination is lower than $10 \%$, the effect on $\delta^{13} \mathrm{C}$ is considered to be negligible and the base-acid treatment can be avoided (Vaiglova et al., 2014). In this respect, a selection of charcoal samples from each level of the stratigraphy was analyzed by infra-red spectrometry with a PerkinElmer Frontier FTIR spectrometer coupled to the Spectrum software. No significant humic contamination was observed and, thus, only the pre-treatment for carbonates was applied.

The decarbonation method is based on (DeNiro and Hastorf, 1985), which had previously been applied to burnt archaeological remains (Aguilera et al., 2012; Ferrio et al., 2006). Charcoal samples were soaked individually (sufficient mass) with $1 \mathrm{M} \mathrm{HCl}$ for $45 \mathrm{~min}$ at $80^{\circ} \mathrm{C}$, then rinsed repeatedly with distilled water to a neutral $\mathrm{pH}$.

\section{$\underline{\text { Isotopic analysis }}$}

An isotopic and elemental analysis $\left(\delta^{13} \mathrm{C}\right.$ and $\left.\% \mathrm{C}\right)$ was performed with an Elementar Vario Pyrocube coupled to continuous flow Isoprime 100 isotope ratio mass spectrometer at the Oceanography Laboratory of Villefranche (LOV, CNRS/SU). The usual internal calibration procedures with standards and blanks were applied, with a caffeine standard (isotopically certified, AIEA-600) calibrated relative to $\mathrm{V}-\mathrm{PDB}$, and a secondary standard calibrated with the caffeine (acetanilide from Merck, CAS 103-84-4). Standard variability and error analyses were in the range of $0.1 \%$. $\delta^{13} \mathrm{C}$ values were corrected using a monopoint standard correction (Paul et al., 2007) and were reported per mille.

\section{Data processing}

First, we observed that all charcoal samples recorded the same carbon content $(\% \mathrm{C})$ of around $60 \%$. Correlation observed between the decrease in $\delta^{13} \mathrm{C}$ and the increase in $\% \mathrm{C}$ allowed to propose a relative same carbonization impact on the charcoal (Audiard et al., 2018; Ferrio et al., 2006). Since our samples record the same degree of carbonization, no correction was applied.

With regard to atmospheric parameters, Les Canalettes are dated around $73500 \pm 6000$ years BP (Valladas et al., 1987) with relatively fast site filling. The average $\delta^{13} C_{a t m}$ for this period is relatively stable $\left(<0.1 \%\right.$ o for the range $\delta^{13} C_{\text {atm }}$ between $80 \mathrm{ka}$ and $\left.66 \mathrm{ka}\right)$ and precedes the relatively strong decrease around $60 \mathrm{ka}\left(\delta^{13} \mathrm{C}_{\text {atm }}\right.$ from $-6.92 \%$ o to $58 \mathrm{ka}$ for $-6.47 \%$ o to $66 \mathrm{ka}$ ) (Eggleston et al., 2016). At the same time, the maximum evolution of the $\mathrm{CO}_{2}$ atm concentration does not exceed $25 \mathrm{ppmv}$ (between 82.8 and $68.5 \mathrm{ka}$ ) with gradual variations compared to the current conditions (234 ppmv to $82.8 \mathrm{ka} ; 219.5 \mathrm{ppmv}$ to $76.8 \mathrm{ka} ; 243 \mathrm{ppmv}$ to $70.7 \mathrm{ka} ; 226 \mathrm{ppmv}$ to $68.5 \mathrm{ka}$ ) (Barnola et al., 1987). However, without abrupt changes, we expect plants to adapt their physiology and maintain a constant $\mathrm{ca} / \mathrm{ci}$ ratio and negligible isotopic impact (Ehleringer and Cerling, 1995). Hence, no atmospheric correction was applied to the isotopic signal. One of the most important variations of the Würm (which remains slow compared to the present one) is observed between $70.7 \mathrm{ka}$ and $62 \mathrm{ka}$, with a decrease of 50 ppmv (Barnola et al., 1987). Thus, a slight negative impact can occur on the $\delta^{13} \mathrm{C}$ during possible contemporaneous occupation. This possible impact has to be considered in the interpretation of the $\delta^{13} C_{\text {atm }}$ from charcoal of the upper part of US 2 . 
Lastly, thanks to the high sampling resolution, a $\delta^{13} \mathrm{C}$ mean and standard deviation for each artificial sub-stratigraphic unit are calculated.

\section{Results}

The raw results are synthesized below by artificial stratigraphic sub-unit (décapage, Dec) and US in Table 1, and are then compared with the charcoal taxonomic and microfaunal data in Figure 4.

Firstly, we observed relative low variability by décapage. The isotopic standard deviation between charcoal from the same décapage does not exceed $1 \%$ and is mainly lower than $0.5 \%$. Moreover, except for Dec 8 in the US 2 (3.3\%o), no décapage shows isotopic deviation above $2.5 \%$, and more than $2 / 3$ of the $\delta^{13} \mathrm{C}$ max deviation stayed lower than $2 \%$. Comparatively, we observed a higher $\delta^{13} \mathrm{C}$ max deviation by US, up to $3.8 \%$ for US 2 and up to $2.8 \%$ for US 3 and 4 . However, the standard deviations remain relatively low ( 0.5 and $0.6 \%$, respectively), whereas those from US 2 reach $1.0 \%$ (equal to maximum standard deviation by décapage).

\begin{tabular}{|c|c|c|c|c|}
\hline $\begin{array}{c}\text { Stratigraphic } \\
\text { Level }\end{array}$ & $\mathbf{N}$ & $\begin{array}{c}\text { Mean } \delta^{13} \mathrm{C} \\
(\% \circ)\end{array}$ & $\begin{array}{c}\delta^{13} \mathrm{C} \text { standard } \\
\text { deviation } \\
(\%)\end{array}$ & $\begin{array}{c}\delta^{13} \mathrm{C} \text { max } \\
\text { deviation } \\
(\% \text { o })\end{array}$ \\
\hline $\operatorname{Dec} 8$ & 18 & -25.4 & 1.1 & 3.3 \\
\hline Dec 9 & 10 & -25.5 & 0.7 & 1.3 \\
\hline Dec de 1985 & 2 & -23.9 & 0.2 & 0.3 \\
\hline US 2 & 30 & -25.3 & 1.0 & 3.8 \\
\hline Dec 20 & 8 & -24.6 & 0.2 & 0.4 \\
\hline Dec 35 & 10 & -25.0 & 0.2 & 0.5 \\
\hline Dec of 1987 & 11 & -25.4 & 0.5 & 1.7 \\
\hline Dec of 1988 & 9 & -24.9 & 0.8 & 2.5 \\
\hline US 3 & 38 & -25.0 & 0.6 & 2.8 \\
\hline Dec 51 & 9 & -25.0 & 0.5 & 1.6 \\
\hline Dec 57 & 11 & -25.0 & 0.5 & 2.0 \\
\hline Dec 62 & 10 & -24.5 & 0.6 & 2.1 \\
\hline Dec 68 & 10 & -24.8 & 0.8 & 2.3 \\
\hline Dec 72 & 5 & -24.5 & 0.5 & 1.1 \\
\hline Dec 73 & 5 & -24.7 & 0.5 & 1.2 \\
\hline US 4 & 50 & -24.7 & 0.6 & 2.8 \\
\hline Mean & 9 & -24.9 & 0.5 & 1.6 \\
\hline
\end{tabular}

Table 1: Summary of isotopic data obtained from Les Canalettes charcoal remains, with $\mathrm{N}$ being the number of charcoal samples analyzed individually.

Furthermore, a mean $\delta^{13} \mathrm{C}$ variation up to $0.5 \%$ for US 4 , up to $0.8 \%$ for US 3 and up to $1.6 \%$ for US 2 is observed between different décapages from the same US. In general, we observed a $\delta^{13} \mathrm{C}$ decrease during the sequences, with a difference of $0.6 \%$ between the lowest and uppermost décapage (Dec 73 - US 4 with $-24.7 \%$ and Dec 8 - US 2 with -25.3\%o, respectively).

On a finer scale, we first observed low fluctuation of the isotopic mean until « Dec 68 " of US 4 (between -24.8 et $-24.5 \%$ ), then a decrease to the end of US $4(-25.0 \%)$ and which continues in US 3 until the Dec of $1987\left(-25.4 \%\right.$ ). From Dec 3, the mean $\delta^{13} \mathrm{C}$ increases in the last décapages (up to 
24.6\%o). This increase continues with the first décapage in US 2 (Dec of 1985; up to -23.9\%o). However, it is important to note that this mean value was obtained with only two charcoal samples. Lastly, the last two décapages of US 2 are marked by a low mean $\delta^{13} \mathrm{C}(-25.5$ and $-25.4 \%$ ), with an abrupt decrease at Dec $9(-23.9$ to $-25.5 \%$ ). However, we noted that the final décapage (Dec 8 ) has the highest standard deviation and maximum deviation of $\delta^{13} \mathrm{C}$ for the site (1.1\%o and $3.3 \%$, respectively).

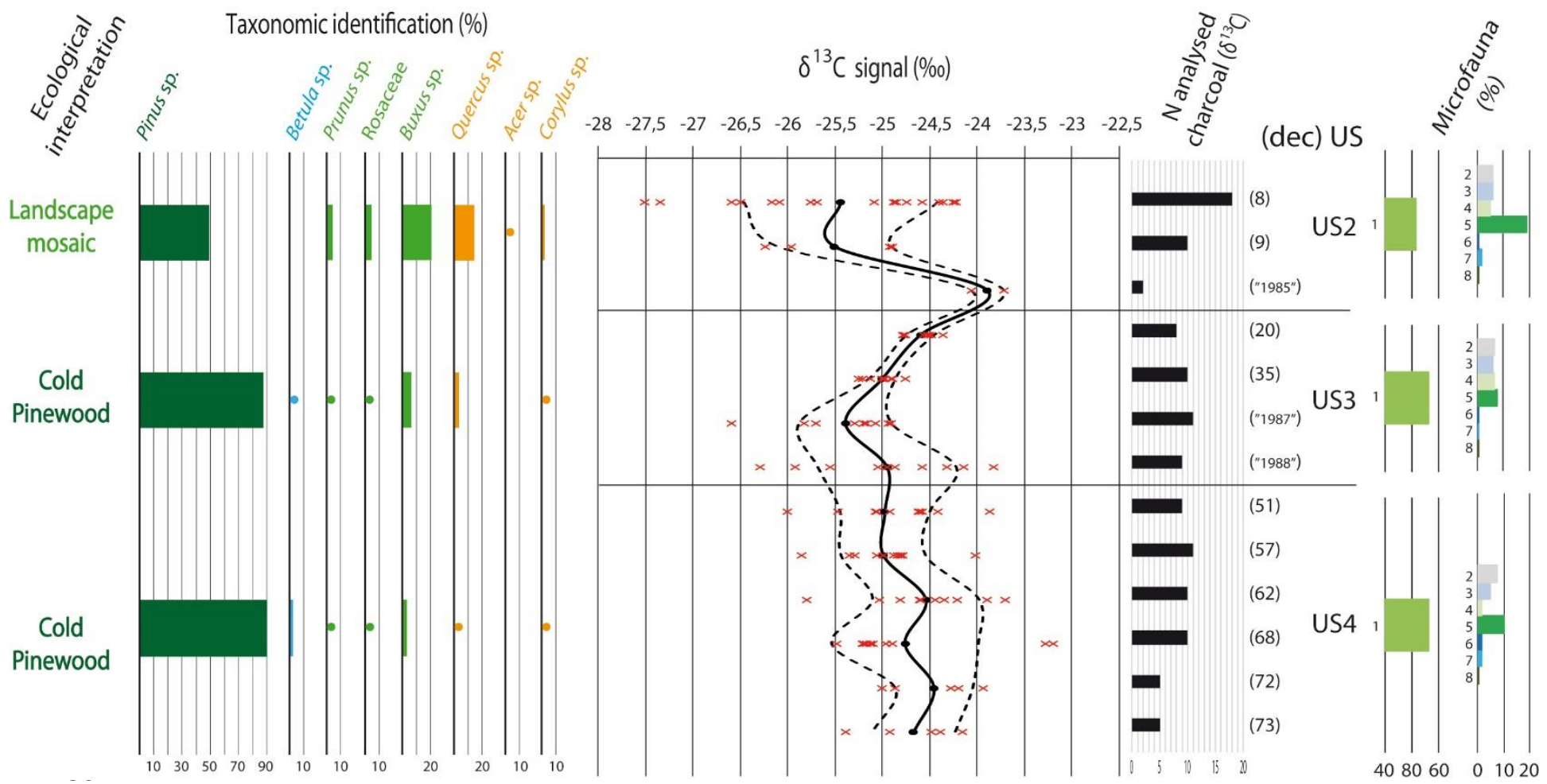

Figure 4: Summary of the isotopic data obtained from charcoal remains, supplemented by previous paleoenvironmental data from Les Canalettes rock shelter. We observed, from left to right: (i) the anthracological identification by US and the ecological interpretations (Vernet, 1993; Théry-Parisot, 1998); (ii) the synthetic graph of the isotopic data with, according to the stratigraphy, the mean $\delta^{13} \mathrm{C}$ (continuous black line), the standard deviations by level of the $\delta^{13} \mathrm{C}$ (dotted black line) and the individual isotopic values obtained for each charcoal sample (red cross); (iii) $\mathrm{N}$ the number of charcoal samples analyzed per stripping; (iv); décapage and stratigraphic unit $(v)$ microfaunal data represented by percentage of typical ecological groups, with the following numbers: arctic steppes (1), boreal swampy open spaces (2), very arid continental steppes (3), not very arid open spaces (4), grasslands and wetlands (5), waterfronts (6), heliophilic rock groups (7) and temperate forests (8) (Marquet, 1995).

\section{Interpretation}

The variability of the mean isotopic signal between décapages is relatively large (for the most pronounced changes) compared to the standard deviation of the $\delta^{13} \mathrm{C}$ for each décapage. The evolutions of the mean $\delta^{13} \mathrm{C}$ are considered to be significant (correlated to the climatic and environmental signal) and not only due to the restricted sampling and the variability of the signal (intraindividual, inter-individual, seasonal/annual variations; highlighted by maximum isotopic deviation). However, even if the $\delta^{13} \mathrm{C}$ mean of Dec of 1985 follows the isotopic increase observed in US 3, the fact that only two charcoal samples were analyzed raises question about the representativity of the signal. However, despite a high number of analyzed charcoal samples, the significant mean $\delta^{13} \mathrm{C}$ variability in Dec 8 (US 2) deserves to be highlighted too. 
The climatic interpretations of the isotopic signal evolution are based on current knowledge of the wood $\delta^{13} \mathrm{C}$ (Cernusak and English, 2015; McCarroll and Loader, 2004). However, it is possible that the low atmospheric carbon content ( $<243 \mathrm{ppmv})$ amplified plant sensitivity to climate change (particularly factors linked to water availability) and thus the isotopic signal (Beerling, 1994; Beerling and Woodward, 1995; Ehleringer and Cerling, 1995). Therefore, independently of atmospheric temperature, decreasing trends of the $\delta^{13} \mathrm{C}$ signal are interpreted as a wet and/or favorable environment for plant growth (e.g. soil development) and conversely for an increasing trend (dry and/or unfavorable environment for growth). Nevertheless, in relative wet conditions and/or significant warming, temperature can also trigger variation of isotope signal (positive trend corresponding to higher temperature and vice versa).

Consequently, the general decrease of the isotopic mean signal from the base to the top of the sequence can be interpreted as an increase in moisture, better edaphic conditions and/or possible colder climate. Nevertheless, this general trend is not linear but is interrupted by an increasing isotopic phase between US 3 and US 2. Based on what we know about the response of the isotope signal, two hypotheses can be proposed: (i) a dry episode and/or (ii) a warm episode.

In this context, human occupations in Les Canalettes were contemporaneous, first in a wet increase phase in a cold environment $\left(\delta^{13} \mathrm{C}\right.$ decrease; US 4 to US 3$)$, then a significant temperature increase or dry episode $\left(\delta^{13} \mathrm{C}\right.$ increase; US $\left.3 / 2\right)$, to finish with a return to cool and relatively wet conditions (lowest $\delta^{13} \mathrm{C}$; top of US 2), i.e. continuous occupation independent of climatic variations. The significant isotopic variability in the last décapage (Dec 8) may correspond to higher inter-tree variability, which can be explained by (i) an expansion of the wood harvesting area to include different environments (forest or plateau), (ii) a mix of charcoal from different climatic periods, or (iii) a difference in the physiology of the collected trees (resulting from differential adaptation to the extreme climatic event).

Furthermore, the possibility to crossing isotopic and taxonomic data from the same charcoals

\section{Discussion}

\section{Isotopic signal variability}

One of the most important issues that arises from this study is related to the 
samples reveals the same degree of carbonization and allowed us to avoid a "carbonization correction" of the values in $\delta^{13} \mathrm{C}$ (Audiard et al., 2018; Ferrio et al., 2006). However, this observation had already been made in a previous study of Paleolithic charcoal (Audiard et al., 2019). This phenomenon could be a response to differential resistance to the post-deposition process. Insufficient carbonization (charred wood) could lead to natural degradation, whereas excess carbonization ( $400-450^{\circ} \mathrm{C} ; \mathrm{C} \% \approx 60 \%$ ) could lead to loss of cellulose (Czimczik et al., 2002). This would subsequently lead to a decrease in the robustness of the charcoal structure in the face of taphonomic processes, which is particularly important in paleolithic sequences (Chrzazvez et al., 2014; Théry-Parisot et al., 2010). Thus, given the limited impact of carbonization, the observed variability in $\delta^{13} \mathrm{C}$ must mainly be related to natural variability and climatic/environmental recording.

Given the relatively large size of the milled charcoal (over $2 \mathrm{~mm}$ ), the $\delta^{13} \mathrm{C}$ value corresponds to the mean of the isotopic signal recorded across several tree rings, which resulted in the loss of the high-frequency (annual) isotopic resolution to yield a low-frequency (multi-year) recording. The variability is thus should mainly represented by the inter-tree variability.

In this study, the maximum deviation of the isotopic signal, for one décapage, usually does not exceed $2 \%$, with an average of $1.6 \%$. The standard deviation is consistently less than $1.0 \%$, with an average of $0.5 \%$. These values are similar to those obtained for inter-individual (intra-genre) variability in current wood studies (maximum variability from 1 to $3 \%$ o between contemporaneous tree-rings) (Francey, 1981; Leavitt, 2010; Leavitt and Long, 1984, 1986; Mazany et al., 1980; McCarroll and Pawellek, 1998). In particular, our values correspond to those obtained from a study of 100 Scots pine (95\% margin of the mean of $2.02 \%$ and standard deviation of $0.56 \%$ ) (Loader et al., 2013). In another study, a minimum number of trees, between 15 and 30 , is proposed to obtain a representative mean $\delta^{13} \mathrm{C}$ of the low-frequency climatic signal (Esper et al., 2015). Thus, considering the variability of $\delta^{13} \mathrm{C}$ mostly represents inter-individual variability, we can assume an optimal sampling to obtain low frequency signal between 15-30 charcoals. Nevertheless, depending on the charcoal size, we can readily obtain a mean $\delta^{13} \mathrm{C}$ from a low number of charcoal samples that correlate with a low frequency climatic signal. Here, our charcoal analyzed number remain relatively low, by comparison, and show the importance of increasing the sampling as much as possible. Unfortunately, the study on one square meter (to avoid stratigraphic evolution) limits the number of Pinus charcoal remains compared to the need for more robust data.

Nevertheless, the larger change in the mean isotopic signal compared to the standard deviation of the $\delta^{13} \mathrm{C}$ for each décapage (for the most pronounced changes), and the correlation with other paleoenvironmental proxies (microfauna, anthracology) suggest correlation with a low frequency climatic signal. Therefore, the isolated $\delta^{13} \mathrm{C}$ value can be interpreted as a possible isolated tree (different micro-climatic conditions, inter-tree variability) and the increase in the $\delta^{13} \mathrm{C}$ variability could be the result of a larger harvest area (creating different micro-environmental conditions) or a population split (different physiological adaptation to the climate or atmospheric parameters). In this context, our results are consistent with those of La Combette (MIS5-4, Vaucluse, France) (Audiard et al., 2019). Indeed, in this study, isotopic analyses on pooled charcoal samples (by artificial substratigraphic unit) revealed the strong potential for $\delta^{13} \mathrm{C}$ to be used as a climatic proxy, with the main obtained values being lower than the inter-tree variability (error margin of the isotopic wood study). However, this study highlights the loss of information in the case of charcoal pooling. Indeed, by using the mean $\delta^{13} \mathrm{C}$ value of several charcoal samples, we mitigate the real isotopic variability (variability with individual value). Thus, it does not provide information on the extent of inter-tree variability or the reliability of the signal. 
401

402

403

404

405

406

407

408

409

410

411

412

413

414

415

416

417

418

419

420

421

422

423

424

425

426

427

428

429

430

431

432

433

434

435

436

437

438

439

440

441

442

Crossing the isotopic signal and anthracologique (and macrofaunal observations), allowed us to confirm the hypothesis of climatic/environnement improvement throught the Canalettes's sequences (Marquet, 1993, 1995; Théry-Parisot, 1998; Vernet, 1993), with a general humidity increase and the likely passage from relatively cold conditions in the basis of the sequence (US4-3), then a warming episode (US 3 to 2), and finally a return to cooler conditions.. Thus, the hypothesis of climatic deterioration, which was proposed based on the faunal study, seems less likely (Brugal, 1993, 1995). However, the presence of taxa from cold environment observed in the faunal study of US 2 could correlate with a decrease in temperature, which could explain, in part, the low $\delta^{13} \mathrm{C}$ at the top of US 2 (high humidity and temperature decrease).

In a general context, Les Canalettes is contemporaneous of the MIS 5/4 transition known in ice core as the beginning of temperature decreasing and the glacial period (Johnsen et al., 2001). However, about 20 episodes of rapid warming have been recorded in the ice core data and are distributed along the last glacial phase. These warming episodes can reach more than 5 to $15^{\circ} \mathrm{C}$ in Greenland within about 10 years and are followed by slow cooling: "Dansgaard-Oesschger" (D/O) interstages (Cacho et al., 1999; Dansgaard et al., 1989; Schulz, 2002). Thus, the first beginning of MIS 4 is then marked by a succession of cold events (Herinrich 7-a and 7-b) and thaws (D/O events 20 and 19) before the onset of glacial conditions sensu stricto (ibid). In France, similar variations are observed in the pollen diagram of La grande Pile with more humid episodes in a cold context (forest recovery of Pinus and Betula ; Ognon I and II event) (de Beaulieu and Reille, 1992; Helmens, 2014; Woillard, 1978). This phenomenon is also known in the Echets sequences by an considerable increase of Isoetes (de Beaulieu and Reille, 1984), or in the Massif Central (Lanterne II pollen period; Bouchet/Ribains) by fluctuations in Pinus reconquest (Reille and Beaulieu, 1988, 1990). More locally, in the south-east France, similar improvements were observed in climatic archive (geomorphology, microfauna, anthracology) of several other archeological sites dated from the beginning of the MIS5/4 transition : Baume de MoulaGuercy, Saint-Marcel, Abri des Pêcheurs and Abri Maras in Ardèche (Defleur and Desclaux, 2019; Desclaux and Defleur, 1997; Hardy et al., 2013; Kalaï, 1998; Moncel et al., 2008; Moncel et al., 2010; Moncel et al., 2004) or les Calmettes in the Gard (Bazile-Robert, 1979) and la Combette in the Vaucluse (Audiard et al, 2019).

In that context, the general increase of humidity through the Canalette's sequences could correspond to the transition between a cold and dry environment during the very beginning of MIS4 to wetter conditions contemporary of the climatic events mentioned above. Moreover, while it seems difficult to correlate our local isotopic episode with a global-scale climate event (recorded in ice cores), a less intense climate event can still be envisaged in the region. The rapid temperature evolution would have been such that plant physiology would not have been able to adapt. In contrast, if the decrease of the mean $\delta^{13} \mathrm{C}$ corresponds to a temperature decrease with relative humid conditions, it is possible to consider plant adaptation to higher temperatures. Some authors propose that climate rapidly affects the phenotypic and genotypic selection of individuals over only a few generations (Anderson et al., 1996; Ferrio et al., 2003b). Furthermore, this adaptation could explain, in part, the highest variability of the isotopic signal in the top sequence. Nevertheless, without complementary data, this increase in the variability most likely corresponds to a larger harvest zone (different environmental conditions) or a mix of charcoal from different climatic periods (climate change record by one tree population or different tree populations collected during several occupations). 
One of the aims of this study is to shed light on Neanderthal behavior by comparing taxonomic and isotopic data. Here, correlations between the general trend of the mean $\delta^{13} \mathrm{C}$ and the charcoal analysis support the hypothesis that the taxonomic assemblage is representative of the forest composition over time. This hypothesis is consistent with a non-selective wood harvest by the Neanderthals of Les Canalettes. The presence of a relatively large forest in the alveolus of Les Canalettes, dominated by Pinus sp. (with significant natural pruning) certainly favored this practice (Théry-Parisot and Meignen, 2000).

Furthermore, our study shows that the different groups of Neanderthals experienced climatic changes during the different occupation periods. In contrast, the technological organization of the lithic production (raw material acquisition, tool production and maintenance) and the subsistence strategies in terms of animal resource acquisition and treatment are constant through the stratigraphic sequence (Brugal, 1993; Lebegue, 2012; Meignen, 1993b; Meignen et al., 2001; Pathou-Mathis, 1993). Moreover, the settlement patterns (long-term and repetitive human occupations corresponding to base camps, concentrated in the good season) remained the same throughout this period (Brugal, 1993; Lebegue, 2012; Meignen, 1993a; Pathou-Mathis, 1993; Roussel et al., 2019). This opposition between environmental/climatic changes and the technical and cultural continuity (e.g. lithic traditions, subsistence strategies, lignite gathering) that characterizes the occupations of the site, reflects the persistence of strong cultural traditions independent of climatic conditions (huntergatherer mobility organized around seasonal occupations of this rock shelter on the Causse). The transmission of the knowledge regarding such a strategic supply area in a relatively vast environment (Causses, valleys, etc.), has most certainly favored this cultural continuity.

\section{Conclusion}

This is the first isotopic study $\left(\delta^{13} \mathrm{C}\right)$ of isolated charcoal (individual values) in a Pleistocene sequence in Europe. The use of this method on the charcoal remains of Les Canalettes shelter has thus been able to show:

- $\quad$ Relatively low variability of the isotopic signal by décapage (artificial sub-stratigraphic unit) compared to the evolution of the mean $\delta^{13} \mathrm{C}$ signal along the sequence.

- A correlation between the general isotope signal data and other paleoenvironmental data (anthracology, microfauna). A general decrease in aridity is thus observed during the different successive occupations (general trend).

- The possibility to obtain an isotopic signal representative of environment/climatic with relatively small number of charcoal (ideally 15-30 charcoals but less big charcoals can be already indicative). It provides a high-resolution signal, complementary of the anthracological data. Thus, we observe global warming between layers 3 and 2 (not observable with the other climate markers). However, interpretation without an anthracological taxonomic background is still complicated.

- Finally, the cross-referencing of isotope and taxonomic analyses support the hypothesis of climate change and dismissed the assumption of a change in wood harvesting behavior in US 2.

- Cultural sustainability of technical knowledge and pattern of territory exploitation, despite observed climate change 
Based on the study of a lower number of charcoal samples than a classical charcoal analysis, isotopic analysis provides a higher resolution stratigraphic signal, which is rarely possible in Pleistocene sequences. Applying isotopic analyses to individual charcoal samples from Pleistocene sequences allows us to obtain a reliable climatic proxy with relatively low variability. Our results are in agreement with those of La Combette (MIS5-4, Vaucluse, France) (Audiard et al., 2019) but with a higher resolution. Indeed, in La Combette, isotopic analyses on charcoal pooling (by artificial substratigraphic unit) highlights the loss of information by attenuating the actual isotope variability due to the $\delta^{13} \mathrm{C}$ mean values from several charcoal samples.

This study also highlights the importance of increased numbers of charcoal samples in order to obtain the most reliable signal possible. Moreover, questions about plant adaptation to climatic (or atmospheric) changes arise. Thus, further studies on the variability and responses of the isotope signal to climate change and on complementary Pleistocene sequences are required to consolidate this approach.

\section{Acknowledgements}

This study was co-funded by the Région-Sud (doctoral grant) and by the VEOLIA company ("Les poubelles de la Préhistoire" project, PI Théry-Parisot). We thank the ONF for their partnership. We would also like to thank VEOLIA for essential financial support for our analysis. Diagrams were drawn with software developed by M. Macías from Universitat Politècnica de València.

Aguilera, M., Ferrio, J. P., Pérez, G., Araus, J. L., and Voltas, J., 2012, Holocene changes in precipitation seasonality in the western Mediterranean Basin: a multi-species approach using $\delta 13 \mathrm{C}$ of archaeobotanical remains: Journal of Quaternary Science, v. 27, no. 2, p. 192-202.

Ambert, P., 1993, Présentation géomorphologique de l'abri des Canalettes, in Meignen, L., ed., L'abri des Canalettes. Un habitat moustérien sur les grands Causses (Nant, Aveyron). Fouilles 19801986, Volume 10, CNRS, Monographie du CRA, p. 41-61.

Anderson, J. E., Williams, J., Kriedemann, P. E., Austin, M. P., and Farquhar, G. D., 1996, Correlations between carbon isotope discrimination and climate of native habitats for diverse eucalypt taxa growing in a common garden: Aust J Plant Physiol, v. 23, p. 311-320.

Audiard, B., Blasco, T., Brossier, B., Fiorentino, G., Battipaglia, G., and Théry-Parisot, I., 2018, $\delta 13 C$ referential in three Pinus species for a first archeological application to Paleolithic contexts "Between intra- and inter-individual variation and carbonization effect": JAS: report, v. 20, p. 775-783.

Audiard, B., Thery-Parisot, I., Blasco, T., Mologni, C., Texier, P.-J., and Battipaglia, G., 2019, Crossing taxonomic and isotopic approaches in charcoal analyses to reveal past climates. New perspectives in Paleobotany from the Paleolithic Neanderthal dwelling-site of La Combette (Vaucluse, France): Review of Palaeobotany and Palynology, v. 266, p. 52-60.

Badal, E., Carrión, Y., Grau, E., Macías, M., and Ntinou, M., 2011, Proceedings 5th international meeting of charcoal analysis: The charcoal as cultural and biological heritage, Valencia, Spain, SAGVNTVM papeles del laboratorio de arqueologia de Valencia.

Barnola, J. M., Raynaud, D., Korotkevich, Y. S., and Lorius, C., 1987, Vostok ice core provides 160,000year record of atmospheric CO2: Nature, v. 329, p. 408-414.

Baton, F., Nguyen Tu, T. T., Derenne, S., Delorme, A., Delarue, F., and Dufraisse, A., 2017, Tree-ring $\delta^{13} C$ of archeological charcoals as indicator of past climatic seasonality. A case study from the Neolithic settlements of Lake Chalain (Jura, France): Quaternary International, v. 457, p. 5059. 
Battipaglia, G., Strumia, S., Esposito, A., Giuditta, E., Sirignano, C., Altieri, S., and Rutigliano, F. A., 2014, The effects of prescribed burning on Pinus halepensis Mill. as revealed by dendrochronological and isotopic analyses: Forest Ecology and Management, v. 334, p. 201-208.

Bazile-Robert, E., 1979, Flore et végétation du sud de la France pendant la dernière glaciation d'après l'analyse anthracologique, [PhD: Université de Sciences techniques du Languedoc de Montpellier, $154 \mathrm{p}$.

Beerling, D. J., 1994, Predicting leaf gas exchange and $\delta^{13} \mathrm{C}$ responses to the past 30000 years of global environmental change: The New Phytologist, v. 128, p. 425-433.

Beerling, D. J., and Woodward, F. I., 1995, Stomatal responses of variegated leaves to $\mathrm{CO}_{2}$ enrichment: Annals of Botany, v. 75, p. 507-511.

Brugal, J.-P., 1993, La faune des grands mammifères de l'abri des Canalettes : Matériel 1980-1986., in Meignen, L., ed., L'abri des Canalettes. Un habitat moustérien sur les grands Causses (Nant, Aveyron). Fouilles 1980-1986, Volume 10, CNRS, Monographie du CRA, p. 89-138.

-, 1995, La faune des grands mammifères de l'abri des Canalettes (Fouille 1995), in Meignen, L., ed., L'abri moustérien des Canalettes (Nant, Aveyron), Rapport Tri-annuel 1993-1995.

Cacho, I., Grimalt, J. O., Pelejero, C., Canals, M., Sierro, F. J., and Flores, J. A., 1999, Dansgaard-Oeschger and Heinrich event imprints in Alboran Sea paleotemperatures: Palaeogeography, v. 14, no. 6, p. 698-705.

Cernusak, L. A., and English, N. B., 2015, Beyond tree-ring widths: stable isotopes sharpen the focus on climate responses of temperate forest trees: Tree Physiol, v. 35, p. 1-3.

Chabal, L., 1992, La représentativité paléo-écologique des charbons de bois archéologiques issus du bois de feu: Bulletin de la Société Botanique de France. Actualités Botaniques, v. 139, p. 213236.

-, 1997, Forêts et sociétés en Languedoc (Néolithique final, Antiquité tatdive) : L'anthracologie, méthode et paléoécologie, DAF, 49 p.:

Chrzazvez, J., Théry-Parisot, I., Fiorucci, G., Terralc, J.-F., and Thibaut, B., 2014, Impact of postdepositional processes on charcoal fragmentation and archaeobotanical implications: Experimental approach combining charcoal analysis and biomechanics: Journal of Archaeological Science, v. 44, p. 30-42.

Czimczik, C. I., Preston, C. M., Schmidt, M. W. I., Werner, R. A., and Schulze, E. D., 2002, Effects of charring on mass, organic carbon, and stable carbon isotope composition of wood: Organic Geochemistry, v. 33, p. 1207-1223.

Damblon, F., 2008, Proceedings 4th International Meeting of Anthracology, Brussels, Belgium, BAR International Series.

Dansgaard, W., Whitet, J. W. C., and Johnsen, S. J., 1989, The abrupt termination of the Younger Dryas climate event: Nature, v. 339.

Dawson, T. E., Mambelli, S., Plamboeck, A. H., Templer, P. H., and Tu, P. K., 2002, Stable isotopes in plant ecology: Annual Review of Ecology and Systematics, v. 33, p. 507-559.

de Beaulieu, J. L., and Reille, M., 1984, The pollen sequence of les Échets (France): a new element for the chronology of the Upper Pleistocene: Géographie physique et Quaternaire, v. XXXVIII, no. 1, p. 3-9.

-, 1992, The last climatic cycle at la Grande Pile (Vosges, France), a new pollen profile: Quaternary Science Reviews, v. 11, p. 431-438.

Defleur, A. R., and Desclaux, E., 2019, Impact of the last interglacial climate change on ecosystems and Neanderthals behavior at Baume Moula-Guercy, Ardèche, France: Journal of Archaeological Science, v. 104, p. 114-124.

DeNiro, M. J., and Hastorf, C. A., 1985, Alteration of ${ }^{15} \mathrm{~N} /{ }^{14} \mathrm{~N}$ and ${ }^{13} \mathrm{C} /{ }^{12} \mathrm{C}$ ratios of plant matter during the initial stages of diagenesis: Studies utilizing archaeological specimens from Peru: Geochim. Cosmochim. Acta., v. 49, p. 97-115.

Desclaux, E., and Defleur, A., 1997, Étude préliminaire des micromammifères de la baume de MoulaGuercy à Soyons (Ardèche, France). Systématique, biostratigraphie et paléoécologie: Quaternaire, v. 8, no. 2-3, p. 213-223. 
Eggleston, S., Schmitt, J., Bereiter, B., Schneider, R., and Fischer, H., 2016, Evolution of the stable carbon isotope composition of atmospheric $\mathrm{CO} 2$ over the last glacial cycle: Paleoceanography, v. 31.

Ehleringer, J. R., and Cerling, T. E., 1995, Atmospheric $\mathrm{CO}_{2}$ and the ratio of intercellular to ambient $\mathrm{CO}_{2}$ concentrations in plants: Tree Physiology, v. 15, p. 105-111.

Esper, J., Konter, O., Krusic, P. J., Saurer, M., Holzkämper, S., and Brüntgen, U., 2015, Long-term summer temperature variation in the Pyrénées from detrended stable carbon isotopes: Geochronometria, v. 42, p. 53-59.

Farquhar, G. D., Ehleringer, J. R., and Hubick, K. T., 1989, Carbon isotope discrimination and photosynthesis: Annu. Rev. Plant Phys., v. 40, p. 503-537.

Farquhar, G. D., and Lloyd, J., 1993, Carbon and oxygen isotope effects in the exchange of carbon dioxide between terrestrial plants and the atmosphere, in Ehleringer, J. R., Hall, A.E., Farquhar, G.D., ed., Stable Isotopes and Plant Carbon-Water Relations: New York, Academic Press, p. 47-70.

Farquhar, G. D., O'Leary, M. H., and Berry, J. A., 1982, On the relationship between carbon isotope discrimination and the intercellular carbon dioxide concentration in Leaves: Australian Journal Plant Physiology, v. 9, p. 121-137.

Farquhar, G. D., and Richards, R. A., 1984, Isotopic composition of plant carbon correlates with wateruse efficiency of wheat genotypes: Australian Journal of Plant Physiology v. 11, p. 539-552.

Ferrio, J. P., Alonso, N., Lopez, J. B., Araus, J. L., and Voltas, J., 2006, Carbon isotope composition of fossil charcoal reveals aridity changes in the NW Mediterranean Basin: Global Change Biology, v. 12, p. 1253-1266.

Ferrio, J. P., Voltas, J., and Araus, J. L., 2003b, Use of carbon isotope composition in monitoring environmental changes: Management of Environmental Quality, v. 14, no. 1, p. 82-98.

Fiorentino, G., Caracuta, V., Casiello, G., Longobardi, F., and Sacco, A., 2012a, Studying ancient crop provenance: implications from d13C and d15N values of charred barley in a Middle Bronze Age silo at Ebla (NW Syria): Rapid Commun. Mass Spectrom., v. 26, p. 327-335.

Francey, R. J., 1981, Tasmanian tree rings belie suggested anthropogenic ${ }^{13} \mathrm{C} /{ }^{12} \mathrm{C}$ trends: Nature, v. 290, p. 232-235.

Gagen, M., McCarroll, D., and Edouard, J.-L., 2006, Comining ring width, density and stable carbon isotope proxies to enhance the climate signal in tree-rings : an example from the southern french alps: Climatic Change, v. 78, p. 363-379.

Gagen, M., McCarroll, D., Loader, N. J., Robertson, I., Jalkanen, R., and Anchukaitis, K. J., 2007, Exorcising the "segment length curse": summer temperature reconstruction since AD1640 using non-detrended stable carbon isotope ratios from pine trees in northern Finland: The Holocene, v. 17, p. 433-444.

Gessler, A., Ferrio, J. P., Hommel, R., Treydte, K., Werner, R. A., and Monson, R. K., 2014, Stable isotopes in tree rings: towards a mechanistic understanding of isotope fractionation and mixing processes from the leaves to the wood: Tree Physiol, v. 34, p. 796-818.

Hall, G., Woodborne, S., and Scholes, M., 2008, Stable carbon isotope ratios from archaeological charcoal as palaeoenvironmental indicators: Chemical Geology, v. 247, p. 384-400.

Hardy, B. L., Moncel, M.-H., Daujeard, C., Fernandes, P., Béarez, P., Desclaux, E., Gema Chacon Navarro, M., Puaud, S., and Gallotti, R., 2013, Impossible Neanderthals? Making string, throwing projectiles and catching small game during Marine Isotope Stage 4 (Abri du Maras, France): Quaternary Science Reviews, v. 82, p. 23-40.

Helmens, K. F., 2014, The Last Interglacial-Glacial cycle (MIS 5-2) re-examined based on long proxy records from central and northern Europe: Quaternary Science Reviews, v. 86, p. 115-143.

Johnsen, S. J., Dahl-Jensen, D., Gundestrup, N., Steffensen, J. P., Clausen, H. B., Miller, H., MassonDelmotte, V., Sveinbjörnsdóttir, A. E., and White, J., 2001, Oxygen isotope and palaeotemperature records from six Greenland ice-core stations: Camp Century, Dye-3, GRIP, GISP2, Renland and NorthGRIP: Journal of Quaternary Science, v. 16, no. 4, p. 299-307. 
Kalaï, C., 1998, Reconstitution du paléoenvironnement végétal et du paléoclimat de la fin du Pléistocène moyen et du Pléistocène supérieur d'après les analyses polliniques de la Baume Moula-Guercy, du site de Payre et de l'abri des Pêcheurs (Ardèche, France) [Doctorat: Muséum National d'Histoire Naturelle, $175 \mathrm{p}$.

Kervazo, B., Meignen, L., and O'Yi, W., 1995, Canalettes, étude géologique, in Meignen, L., ed., L'abri moustérien des Canalettes (Nant, Aveyron), Rapport Tri-annuel 1993-1995.

Leavitt, S. W., 2002, Prospects for reconstruction of seasonal environment from tree-ring $\delta^{13} \mathrm{C}$ : baseline findings from the Great Lakes area, USA: Chemical Geology, v. 192, p. 47-58.

,- 2007 , Regional expression of the 1988 U.S. Midwest drought in seasonal $\delta^{13} \mathrm{C}$ of tree rings: J Geophys Res, v. 112, p. D06107.

-, 2010, Tree-ring C-H-O isotope variability and sampling: Science of the Total Environment, v. 408, p. 5244-5253.

Leavitt, S. W., and Lara, A., 1994, South American trees show declining $\delta^{13} \mathrm{C}$ trend: Tellus, v. 46, no. B, p. 152-157.

Leavitt, S. W., and Long, A., 1984, Sampling strategy for stable carbon isotope analysis of tree rings in pine: Nature, v. 311, p. 145-147.

,- 1986 , Stable-carbon isotope variability in tree foliage and wood: Ecology, v. 67, p. 1002-1010.

Lebegue, F., 2012, Le Paléolithique moyen récent entre Rhône et Pyrénées : approche de l'organisation techno-économique des productions lithiques, schémas de mobilité et organisation du territoire (Les Canalettes, I'Hortus, Bize-Tournal, la Crouzade et la Roquette II) [PhD: Université de Liège, $799 \mathrm{p}$.

Loader, N. J., Young, G. H. F., McCarroll, D., and Wilson, R. J. S., 2013, Quantifying uncertainty in isotope dendroclimatology: The Holocene, p. 1-6.

Ludemann, T., and Nelle, O., 2015, Proceedings 6th International Anthracology Meeting : Local to global significance of charcoal science, Freiburg, Germany, Quaternary International Special Issue.

Marquet, J.-C., 1993, Le climat et l'environnement d'après l'étude des rongeurs dans l'abri des Canalettes, in Meignen, L., ed., L'abri des Canalettes. Un habitat moustérien sur les grands Causses (Nant, Aveyron). Fouilles 1980-1986, Volume 10, CNRS, Monographie du CRA, p. 7176.

-, 1995, Etude préliminaire des rongeurs de la couche 4, quelques éléments de réflexion, in Meignen, L., ed., L'abri moustérien des Canalettes (Nant, Aveyron), Rapport Tri-annuel 1993-1995.

Marshall, J. D., and Monserud, R. A., 1996, Homeostatic gas-exchange parameters inferred from $13 \mathrm{C} / 12 \mathrm{C}$ in tree rings of conifers: Oecologia, v. 105, p. 13-21.

Masi, A., Sadori, L., Baneschi, I., Siani, A. M., and Zanchetta, G., 2013, Stable isotope analysis of archaeological oak charcoal from eastern Anatolia as a marker of mid-Holocene climate change: Plant Biology, v. 15, no. 1, p. 83-92.

Mazany, T., Lerman, J. C., and Long, A., 1980, Carbon-13 in tree-ring cellulose as an indicator of past climates: Nature, v. 287, p. 432-435.

McCarroll, D., and Loader, N. J., 2004, Stable isotopes in tree rings: Quaternary Science Reviews, v. 23, p. 771-801.

McCarroll, D., and Pawellek, F., 1998, Stable carbon isotope ratios of latewood cellulose in Pinus sylvestris from northern Finland: variability and signal-strength: The Holocene, v. 8, no. 6, p. 675-684.

-, 2001, Stable carbon isotope ratios of Pinus sylvestris from northern Finland and the potential for extraction a climate signal from long Fennoscandian chronologies: The Holocene, v. 11, p. 517526.

Meignen, L., 1993a, L'abri des Canalettes. Un habitat moustérien sur les grands Causses (Nant, Aveyron). Fouilles 1980-1986, Volume 10, CNRS, Monographie du CRA, 359 p.:

-, 1993b, Les industries lithiques de l'abri des Canalettes : couche 2, in Meignen, L., ed., L'abri des Canalettes. Un habitat moustérien sur les grands Causses (Nant, Aveyron). Fouilles 1980-1986, Volume 10, CNRS, Monographie du CRA, p. 239-328. 
Meignen, L., Brugal, J.-P., Théry-Parisot, I., and Marquet, J. C., 2001, Territorial exploitation, technical traditions and environment in a mid-altitude context: The Canalettes Rockshelter (Grands Causses, France), in Conard, N. J., ed., Settlement dynamics of the Middle Paleolithic and Middle Stone age: Tübingen, kerns Verlag, p. 463-483.

Moncel, M.-H., Brugal, J.-P., Prucca, A., and Lhomme, G., 2008, Mixed occupation during the Middle Palaeolithic: Case study of a small pit-cave-site of Les Pêcheurs (Ardèche, south-eastern France): Journal of Anthropological Archaeology, v. 27, p. 382-398.

Moncel, M.-H., Daujeard, C., Crégut-Bonnoure, É., Boulbes, N., Puaud, S., Debard, É., Bailon, S., Desclaux, E., Escude, É., Roger, T., and Dubard, M., 2010, Nouvelles données sur les occupations humaines du début du Pléistocène supérieur de la moyenne vallée du Rhône (France). Les sites de l'Abri des Pêcheurs, de la Baume Flandin, de l'Abri du Maras et de la Grotte du Figuier (Ardèche): Quaternaire, v. 21, no. 4, p. 389-415.

Moncel, M.-H., Daujeard, C., Crégut-Bonnoure, É., Fernandez, P., Faure, M., and Guérin, C., 2004, L'occupation de la grotte de Saint-Marcel (Ardèche, France) au Paléolithique moyen : stratégie d'exploitation de l'environnement et type d'occupation de la grotte. L'exemple des couches i, j et j': Bulletin de la Société préhistorique française, v. 101, no. 2, p. 257-304.

Olive, M., and Taborin, Y., 1987, Nature et fonction des foyers préhistoriques, Mémoires du musée de Préhistoire d'île-de-France, Actes du colloque international de Nemours, 334 p.:

Panek, J. A., and Goldstein, A. H., 2001, Response of stomatal conductance to drought in ponderosa pine: implications for carbon and ozone uptake: Tree Physiology, v. 21, p. 3337-3344.

Pathou-Mathis, M., 1993, Etude taphonomique et palethnographique de la faune de l'abri des Canalettes, in Meignen, L., ed., L'abri des Canalettes. Un habitat moustérien sur les grands Causses (Nant, Aveyron). Fouilles 1980-1986, Volume 10, CNRS, Monographie du CRA, p. 199238.

Paul, D., Skrzypek, G., and Fórizs, I., 2007, Normalization of measured stable isotopic compositions to isotope reference scales - a review: Rapid Communication Mass Spectrometry, v. 21, p. 30063014.

Ramesh, R., Bhattacharya, S. K., and Gopalan, K., 1985, Dendrochronological implications of isotope coherence in trees from Kashmir Valley, India: Nature, v. 317, p. 802-804.

Reille, M., and Beaulieu, J. L., 1988, History of the Würm and Holocene vegetation in western Velay (Massif Central, France): a comparison of pollen analysis from three corings at Lac du Bouchet: Review of Palaeobotany and Palynology, v. 54, p. 233-248.

-, 1990, Pollen analysis of a long upper Pleistocene continental sequence in a Velay maar (Massif Central, France): Palaeogeography, Palaeoclimatology, Palaeoecology, v. 80, p. 35-48.

Resco, V., Ferrio, J. P., Carreira, J. A., Calvo, L., Casals, P., Ferrero-Serrano, A., Marcos, E., Moreno, J. M., Ramírezg, D. A., Sebastià, M. T., Valladares, F., and Williams, D. W., 2011, The stable isotope ecology of terrestrial plant succession: Plant Ecology \& Diversity, v. 4, no. 2-3, p. 117130.

Robertson, I., Rolfe, J., Switsur, V. R., Carter, A. H. C., Hall, M. A., Barker, A. C., and Waterhouse, J. S., 1997, Signal strength and climate relationships in $13 C / 12 C$ ratios of tree ring cellulose from oak in southwest Finland: Geophys Res Lett, v. 24, no. 12, p. 1487-1490.

Roussel, A., Gourichon, L., Valensi, P., and Brugal, J.-P., 2019, Large game hunting strategies in Middle Paleolithic of Southern France : contribution of dental cementum analysis through the study of the Canalettes rockshelter and Lazaret cave sites, European Association of Archeologists, Sep 2019: Bern, Switzerland.

Schulz, M., 2002, On the 1470-year pacing of Dansgaard-Oeschger warm events: Paleoceanography, v. 17, no. 2, p. 1014.

Seftigen, K., Linderholm, H. W., Loader, N. J., Liu, Y., and Young, G. H. F., 2011, The influence of climate on ${ }^{13} \mathrm{C} /{ }^{12} \mathrm{C}$ and ${ }^{18} \mathrm{O} /{ }^{16} \mathrm{O}$ ratios in tree ring cellulose of Pinus sylvestris $\mathrm{L}$. growing in the central Scandinavian Mountains: Chemical Geology, v. 286, p. 84-93. 
Steinbeiss, S., Schmidt, C. M., Heide, K., and Gleixner, G., 2006, $\delta^{13} \mathrm{C}$ values of pyrolysis products from cellulose and lignin represent the isotope content of their precursors: Journal of Analytical and Applied Pyrolysis, v. 75, p. 19-26.

Tans, P. P., and Mook, W. G., 1980, Past atmospheric CO2 levels and the $13 \mathrm{C} / 12 \mathrm{C}$ ratios in tree rings: Tellus, v. 32, p. 268-283.

Théry-Parisot, I., 1998, Économie des combustibles et paléoécologie en contexte glaciaire et périglaciaire, Paléolithique moyen et supérieur du sud de la France. Anthracologie, Expérimentation, Taphonomie. [PhD: Université de Paris 1, $500 \mathrm{p}$.

-, 2001, Économie des combustibles au Paléolithique, CNRS éditions, Dossier de documentation archéologique.

Théry-Parisot, I., Chabal, L., and Chrzavzez, J., 2010, Anthracology and taphonomy, from wood gathering to charcoal analysis. A review of the taphonomic processes modifying charcoal assemblages, in archaeological contexts: Palaeogeography, Palaeoclimatology, Palaeoecology, v. 291, p. 142-153.

Théry-Parisot, I., and Meignen, L., 2000, Économie des combustibles dans l'abri moustérien des Canalettes, de l'expérimentation à la simulation des besoins énergétiques: Gallia Préhistoire, v. 42, p. 44-55.

Théry, I., Girl, J., Vernet, J.-L., Meignen, L., and Maury, J., 1995, First use of coal: Nature, v. 373, p. 480481.

-, 1996, Coal used at two prehistoric sites in southern Frances : les Canalettes (Mousterian) and les Usclades (Mesolithic): Journal of Archaeological Science, v. 23, p. 509-512.

Vaiglova, P., Snoeck, C., Nitsch, E., Bogaard, A., and Lee-Thorp, J., 2014, Impact of contamination and pre-treatment on stable carbon and nitrogen isotopic composition of charred plant remains: Rapid Commun. Mass Spectrom., v. 28, p. 2497-2510.

Valladas, H., Chadelle, J. P., Geneste, J. M., Joron, J. L., Meignen, L., and Texier, P.-J., 1987, Datations par la thermoluminescence de gisements moustériens du sud de la France: I'Anthropologie (Paris), v. 91, no. 1, p. 211-226.

Vernet, J.-L., 1993, Analyse anthracologique de l'abri des Canalettes, in Meignen, L., ed., L'abri des Canalettes. Un habitat moustérien sur les grands Causses (Nant, Aveyron). Fouilles 1980-1986, Volume 10, CNRS, Monographie du CRA, p. 63-70.

Vernet, J.-L., Pachiaudi, C., Bazile, F., Durand, A., Fabre, L., Heinz, C., Solari, M.-E., and Thiébault, S., 1996, Le $\delta^{13} \mathrm{C}$ de charbons de bois préhistoriques et historiques méditerranéens, de $35000 \mathrm{BP}$ à l'actuel. Premiers résultats: C.R. Acad. Sci. Paris, v. 323, no. Ila, p. 319-324.

Voltas, J., Ferrio, J. P., Alonso, N., and Araus, J. L., 2008, Stable carbon isotopes in archaeobotanical remains and palaeoclimate: Contribution to Science, v. 4, no. 1, p. 21-31.

Warren, C. R., McGrath, J. F., and Adams, M. A., 2001, Water availability and carbon isotope discrimination in conifers: Oecologia, v. 127, no. 476-486.

Woillard, G. M., 1978, Grande Pile peat bog: a continuous pollen record for the 140,000 years: Quaternary Research, v. 9, p. 1-21. 